\title{
The feminine image of Russia in the religious and philosophical writings by Russian thinkers at the turn of the 20th century
}

\author{
Arcady G. Sadovnikov ${ }^{*}$, Alina E. Korzheva ${ }^{2}$, and Farrukh Begidjon Khudoidodzoda ${ }^{3}$ \\ ${ }^{1}$ Linguistic University of Nizhny Novgorod, Academic Department of Russian National Studies and \\ Slavic Studies, Nizhny Novgorod, Russia \\ ${ }^{2}$ Linguistic University of Nizhny Novgorod, Scientific Research Laboratory "Fundamental and \\ Applicative Research of Aspects of Cultural Identification", Nizhny Novgorod, Russia \\ ${ }^{3}$ Tajik National University, Dushanbe, Republic of Tajikistan
}

\begin{abstract}
The article looks at the versions of the feminine image of Russia in the religious and philosophical reflections of the Russian thinkers who worked during the Silver Age (the period of Russian culture covering approximately 1890-1917): Vladimir Solovyov, Nikolai Berdyaev, and Sergei Bulgakov. Special attention is paid to the balance between the male and female principles, which are endowed with certain characteristics in different works by Russian thinkers, not only from the perspective of human nature but also in terms of the nature of Russian culture and mentality, as well as the cosmic nature of the universe. Analysis of the religious and philosophical pursuit of the Silver Age relating to the feminine image of Russia allows the authors to specify the ideas of the characteristics of femininity engrained in the Russian culture and clarify the role of this pursuit in the development of the reflexive Russian thought directed towards becoming aware of these characteristics. The belief about the salvatory mission carried out by the feminine aspect of the human and cosmic nature distinctively identified in the religious and philosophical writings by the Russian thinkers belonging to the Siver Age requires further study. The research has been conducted within the framework of the symbolic direction of cultural studies with the help of comparative analysis, the method of theoretical reconstruction, and problematic-logical, functional, and systemic approaches. These methods allowed the authors to specify the problematic field of the research and define the main concepts to examine the statements about the feminine aspect of Russian culture by different authors as a unified system of forms aimed at the comprehension of the value and symbolic foundation of the national ethnic culture.
\end{abstract}

Keywords: femininity, feminine aspect, the Silver Age, religious research.

\footnotetext{
${ }^{*}$ Corresponding author: agsad@yandex.ru
} 


\section{Introduction}

In his book "Europe and The Eastern Soul" W. Schubart, a German philosopher, wrote, "Different nations gave different examples of human ideals" [1]. "For Chinese - it is a wise man, for Hindu - it is an ascetic, for Romans - it is an emperor, for England and Spain - an aristocrat, for Prussians - a solider. Russia is seen for the ideal of its woman" [2].

Since ancient times a cult of femininity existed in Rus: in folklore, where female images were often portrayed in an aura of mystery and magic; in religious culture, where the Holy Mother of God is still widely worshipped; and in the writings of Russian poets and writers, where female characters and destinies are inextricably entwined with the soul and destiny of Russia.

Within the Russian cultural tradition, women can hardly be called the weaker sex. This is also recognized in the West [3, 4]. Russian women possess strength, and this is not only the strength to "stop a galloping horse" or "walk into a burning house" [5] but also moral, psychological strength, the power of love in its truly Russian interpretation of lovecompassion, faith, kenotic self-sacrifice, patience, and sympathy [6].

From the personal perspective, some aspects of such strength can be detrimental but taken together in their entirety, they are salvatory from the national perspective. This is what explains the spread of the ideas of women's soteriological mission and the salvatory mission of the female principle in Russia. Hence F. Dostoyevsky's thought, "Woman is more persistent and patient in terms of work; she wants work more seriously than man for the sake of work rather than to seem busy" [7], as well as Schubart's conviction, "We have strong reasons to hope that the Russian people will be saved by Russian woman" [2] and D.S. Merezhkovsky's declaration, "Russia will be saved by Mother" [8].

A variety of female images were created in the Russian literature in the 19th and 20th centuries embodying the female principle, mysterious in its contradictions, as well as the innermost features of the Russian national character. They include the images of Liza Muromskaya, Tatyana Larina, and Masha Mironova created by Alexander Pushkin, Olga Ilinskaya and Agafya Matveevna Pshenitsyna created by Ivan Goncharov, Nikolai Nekrasov's “Russian women”, Ivan Turgenev's girls, and Fedor Dostoevsky's heroines, from "dreamers" to "infernal ladies", etc. $[9,10]$.

By the end of the 19th century the need for philosophical and artistic generalization of the idea of femininity, in particular in the context of Russian national spiritual culture, had become pronounced.

Justifiably, reflections on femininity during the Silver Age were associated with thoughts about the mystery of the Russian soul [4].

\section{Methods}

The research was conducted within the framework of the symbolic direction in cultural studies. It suggests focusing on the semantic aspect of the symbol, the word and the meaning it expresses in their relation to symbolic values of the national ethnic culture and their modifications at certain stages of its development.

The following general methods of the humanities were used in this work:

- comparative analysis, with the help of which the texts within the selected corpus were compared in terms of the degree of symbolic comprehension of the feminine aspect of Russian culture;

- theoretical reconstruction, with the help of which an attempt was made to restore the process of transformation of the existing ideas of the feminine aspect of Russian culture during the Silver Age; 
- the problematic-logical approach, which allowed us to specify the problematic field of the research and define the main concepts;

- the functional approach, which enabled us to view Russian culture as a self-sufficient symbolic system comprised of functionally connected elements;

- the systemic approach, which allowed us to examine the statements about the feminine aspect of Russian culture by different authors as a unified system of forms aimed at the comprehension of the value and symbolic foundation of the national ethnic culture.

\section{Results and discussion}

In their reflections on femininity, poets and philosophers of the Silver Age followed the experience of ancient thinkers - first and foremost, Aristotle's teachings. Aristotle's key idea was the following, "Maleness is form, femaleness is matter. The latter is passive, like woman, while the male principle is active" [11]. The word used by Aristotle to denote matter also includes the concept of being and hints at the mysterious elusive bottomless essence of nature [12].

The male aspect of form and the female aspect of matter are contrasted with each other in the works by N. Berdyaev [13], V. Ern [14], V. Ivanov [15], S. Bulgakov [16], and other thinkers of the Silver Age. Table 1 shows a summary of the features ascribed to the male and female principles by philosophers [17].

Table 1. The features ascribed to the male and female principles.

\begin{tabular}{|l|l|}
\hline The male principle & The female principle \\
\hline Form & Matter \\
\hline Corporeal & Spiritual \\
\hline Rational & Intuitive \\
\hline Well-ordered & Chaotic \\
\hline Active & Passive \\
\hline Structuring & Structured \\
\hline Fertilizing & Fertilized \\
\hline Giving & Receiving \\
\hline Cultural & Natural \\
\hline Apollonian & Dionysian \\
\hline
\end{tabular}

Apollo and Dionysus became popular in the Silver Age culture largely due to the influence of F. Nietzsche's philosophy and his book "The Birth of Tragedy, Or Hellenism and Pessimism".

The dichotomy Apollonian-Dionysian was introduced by F.W.J. Schelling, who believed that two forces coexisted within man: the blind unrestricted raging force embodied by Dionysus and the sensible restricting shaping force represented by Apollo [18].

The Dionysian feminine principle, full of contradictions, was attributed to Russia.

It was most consistently reflected in the writings by N. Berdyaev. Berdyaev relied on the premise that the feminine element is present in any people, which represents the people's force. However, in all Western peoples, "at a certain stage of development the masculine spirit awoke in a nationally determined form and organically shaped the people's force from within".

Russia has not experienced such awakening. Therefore, "the proper balance between the male and female principles has been disrupted" [19]. "The Russian land remained feminine for a long time and, like a bride, waited for a groom from outside" [13].

Berdyaev saw the mystery of Russian history and Russian soul in "a peculiar balance between the feminine and masculine aspects in the Russian national character" [20]. The philosopher also pointed out the femininity of the Slavs many times. 
For instance, in his book "Destiny of Russia", Berdyaev writes,

"There was no knighthood in Russian history, so Russia did not undergo the temper of personal discipline", “...all the masculine $<\ldots>$ shaping things in Russia were in a way foreign, Western European rather than Russian..."

"...Russia $<\ldots>$ is a rebellious and horrendous country in its spontaneity, in its national Dionysism unwilling to be shaped" [20].

Russia's readiness to make sacrifices is also motivated by the nature of Russian religiousness. While "Catholicism armored the soul, provided it with a solid outline and crystal-clear criteria for good and evil" [13], Orthodox Christianity with its cult of sanctity and humility did not encourage building a strong personality or self-discipline of soul.

One of the manifestations of the interest of the Silver Age thinkers in the feminine aspect of Russian culture was their reinterpretation of the image of Saint Sophia (Holy Wisdom), which came to Rus from Byzantium together with Orthodox Christianity. Metropolitan Hilarion, Maximus the Greek, and Zinovy Otensky wrote about Sophia [21]. Cathedrals in Kyiv, Novgorod, Polotsk, and Vologda are dedicated to this saint.

In Russian icons, Saint Sophia was often portrayed as an angel with fiery wings. Maximus the Confessor, a Byzantian theologian of the 7th century, wrote, "For achieving unity with God, we have no other intermediary than Holy Wisdom" [22].

The portrayal of Sophia as an intermediary between God and the world, as the one who prays to God for people and advocates them, allowed her to be perceived as a patron saint and advocate in the philosophical texts of the Silver Age.

Solovyov called Sophia "The guardian angel of the world, overshadowing all creatures with her wings" [23]. Florensky assumed that with respect to the whole creation, "Sophia is a guardian angel..." [24]. Bulgakov characterized sophiology as "theology of salvation" since Sophia the Holy Wisdom shields this sinful yet sacred land $<\ldots>$ and calls Holy Wisdom "a divine veil thrown over the world" [16].

Solovyov played a crucial role in the development of Russian sophiology over the Silver Age. He wrote, "The aim of the global process is achieving unity of the divine with the world soul. The World-Soul is per se only 'an indefinite opportunity for all-encompassing unity", [25]. Interpreted as an eternal image of existence, initial matter, and the World-Soul, Sophia is potential, passive, and, from this perspective, eternally feminine. In Solovyov's philosophy, Sophia, as the World-Soul, firstly, "contains all elements of the world in unity" and, secondly, represents "potential $<\ldots>$ for complete unity" [25].

In the philosophy of the Silver Age, these Sophia's qualities (potentiality and passivity) were used as an argument to prove its femininity [26].

For example, Bulgakov points out, "Sophia only accepts, she contains only what she has received. By the self-surrender of Divine Love, she commences everything in herself. In this sense she is feminine, the one who receives; she is the "Eternal Feminine"" [16].

Philosophers of the Silver Age associated the eternally feminine image of Sophia with the idea of all-encompassing unity.

As E. Troubetzkoy wrote, "Discord reigns the world, but it is missing from the preexistent creative intention of Holy Wisdom, who created the world" [27]. In Bulgakov's interpretation, Sophia is "all-encompassing", "the internal connection of everything with everything", "Sophia is the world soul, i.e. the principle connecting and organizing the world's multiplicity..." [16].

Solovyov assumes that Sophia "is a dual entity; integrating the divine perfection and sinful matter, it is not determined entirely by either of them" [25]. In his mystical reflections on femininity, Solovyov admitted that it constantly faces the danger of contacting dark matters. "Divine Sophia" turns into "desecrated Sophia" embodying sinful femininity obsessed with desires [9]. 
However, remembering that the world was saved due to a woman (Holy Mother of God), Solovyov believed that the eternal feminine from poetic dreams became nearly physical reality and historical truth.

His reflections on Sophia are closely interconnected with thoughts about Russia and its historical messiahship. In "Three speeches in memory of Dostoyevsky" he says, "In one conversation Dostoyevsky applied John the Apostle's vision of a woman clothed with the sun, who cried out in labor and in pain to give birth, to Russia: according to Solovyov, this woman is Russia, who is giving birth to the new Word, which she has to tell to the world. Whether or not this interpretation of the "great sign" is correct, Dostoyevsky did guess the new Word spoken by Russia. This is a word of reconciliation between the East and West in the union of holy truth...

This is the supreme goal of Russia and Dostoyevsky's 'social ideal'. Its foundation is moral rebirth and a spiritual feat accomplished by the whole society and people rather than an individual" [28].

\section{Conclusion}

Thus, it can be concluded that religiousness has had an impact on the formation of the feminine aspect of Russia. The image of Sophia the Holy Wisdom reinterpreted by the thinkers of the Silver Age combines the functions of a patron saint, advocate, prayer, and "the passive opportunity for all-encompassing unity". It is characterized by potentiality and passivity — the features that prove the femininity of its image. This feminine image is inextricably connected with the ideas of the image and character of Russia, as well as of its historical mission. Analysis of philosophical writings of the Silver Age about femininity allows us to specify the content of a female image in Russian consciousness and its reflection in the value system, ideology, and worldview paradigm of Russian consciousness.

\section{References}

1. G.D. Gachev, Natsionalnye obrazy mira. Kosmo-Psikho-Logos [National images of the world. Kosmo-Psikho-Logos] (Progress, Kultura, Moscow, 1995)

2. W. Schubart, Evropa i dusha Vostoka [Europe and the eastern soul], 183-184 (Eksmo, Moscow, 1997)

3. Th. Gautier, Puteshestvie v Rossiyu [Travel to Russia] (Mysl, Moscow, 1988)

4. S. Gutova, Revista De Letras, 56(1), 167-184 (2016)

5. N. Korzhavin, Variatsii iz Nekrasova [Variations from Nekrasov] (1960). Accessed on: December 10, 2020. [Online]. Available: https://www.culture.ru/poems/37916/variaciiiz-nekrasova

6. E. Hellberg-Hirn, Soil and Soul: the symbolic world of Russianness (Ashgate, Aldershot, Brookfield USA, Singapore, Sydney, 1998)

7. F. M. Dostoevskii, Dnevnik pisatelya [A Writer's Diary], in The complete works in 30 volumes, vol. 21 (Nauka, Leningrad, 1972-1981)

8. D. S. Merezhkovskii, 14 dekabrya [December 14th], in Collected works in 4 volumes, vol. 4 (Moskovskiy rabochy, Moscow, 1990)

9. V.Yu. Lebedev, A.V. Fedorov, Vestnik Slavyanskikh Kultur, 2(36), 29-45 (2015)

10. M. Bogović, Eternal female in the poetry of Sofia Parnok and Maria Tsvetaeva (Sveučilište u Zagrebu, Filozofski fakultet, Zagreb, 2018) 
11. Aristotle, Generation of Animals. Translated by A. L. Peck. Loeb Classical Library 366 (Harvard University Press, Cambridge, MA, 1942)

12. J. Evola, Metafizika pola [Metaphysics of sex], Translated from French (Belovode, Moscow, 1996)

13. N.A. Berdyaev, Filosofiya neravenstva [The philosophy of inequality] (Nauka, Moscow, 1990)

14. V.F. Ern, Mech i krest [Sword and cross], in Collected works (Prada, Moscow, 1991)

15. V.I. Ivanov, O dostoinstve zhenshchiny [On woman's dignity], in Po zvezdam (Ory, Saint Petersburg, 1909)

16. S.N. Bulgakov, Svet nevechernii: Sozertsaniya i umozreniya [Non-evening light: Contemplations and Speculations] (Respublika, Moscow, 1994)

17. M. Makieno, Procedia - Social and Behavioral Sciences, 166, 18-23 (2015)

18. F.W.J. Schelling, Filosofskie issledovaniya o sushchnosti chelovecheskoi svobody $i$ svyazannykh s nei predmetakh [Philosophical inquiries into the essence of human freedom and connected issues], in Writings, vol. 2 (Mysl, Moscow, 1989)

19. N.A. Berdyaev, Mirosozertsanie Dostoevskogo [Dostoyevsky's world outlook], in Filosofiya tvorchestva, Vol. 2 (Nauka, Moscow, 1990)

20. N.A. Berdyaev, Sudba Rossii: Opyty po psikhologii voiny i natsionalnosti [Destiny of Russia: experiments on psychology of war and nationality] (Nauka, Moscow, 1990)

21. I.V. Emelkina, Zhenstvennost v kontekste pravoslavnoi kultury, in The Proceedings of the All-Russian Cyril and Methodius Readings, Saransk, Russia, 23-31 (2018)

22. S.S. Averintsev, K uyasneniyu smysla nadpisi nad konkhoi tsentralnoi apsidy Sofii Kievskoi [Clarification of the meaning of the writing over the conch of the central apse of Saint Sophia Cathedral in Kyiv], in Drevnerusskoe iskusstvo: Khudozhestvennaya kultura domongolskoi Rusi (Nauka, Moscow, 1972)

23. V.S. Solovyov, Rossiya i vselenskaya tserkov [Russia and the universal church] (Put', Moscow, 1911)

24. P.A. Florensky, Stolp i utverzhdenie istiny [The pillar and ground of the truth], in 2 volumes, vol. 1 (Pravda, Moscow, 1990)

25. V.S. Solovyov, Chteniya o Bogochelovechestve [Lectures on divine humanity], in Collected works, vol. 2 (Sovetskaya Rossia, Moscow, 1989)

26. C. Matthews, Sophia Goddess of wisdom: The divine feminine from black Goddess to world soul (HarperCollins, New York, 1991)

27. E.N. Troubetzkoy, Rossiya v ee ikone [Russia in its icons] (Russkaya mysl', Moscow, 1917)

28. V.S. Solovyov, Tri rechi v pamyat Dostoevskogo [Three speeches in memory of Dostoyevsky], in Collected works, vol. 2 (Sovetskaya Rossia, Moscow, 1990) 